\title{
Challenges in Early Infant Diagnosis of Beta Thalassemias
}

\author{
Tika Adilistya*1 and Landelina Lany ${ }^{2}$ \\ ${ }^{1}$ Department of Clinical Pathology and Laboratory Medicine, Dr Kanujoso Djatiwibowo Hospital Balikpapan, Indonesia \\ ${ }^{2}$ Department of Paediatrics, Dr Kanujoso Djatiwibowo Hospital Balikpapan, Indonesia
}

Received: February 21, 2018; Published: February 28, 2018

*Corresponding author: Tika Adilistya, Department of Clinical Pathology and Laboratory Medicine, Dr Kanujoso Djatiwibowo Hospital Balikpapan, Indonesia, Email: dr.adilistya@gmail.com

\section{Introduction}

Thalassemias are a heterogeneous group of genetic disorders that result from a reduced rate of synthesis of $\otimes$ or $\beta$ chains. The genetic defects of hemoglobin are the most genetic disorders worldwide. They occur in tropical and subtropical areas and most appear to have been selected because the carrier state affords some protection against malaria. Indonesia is among a group of countries with high prevalence of thalassemias. The burden of this disorder in the country is of such a magnitude that it represents a major public health concern. Laboratory diagnosis of thalassemia, which consists of blood film examinations and hemoglobin electrophoresis, are the most common modalities in our country since DNA analysis for $\mathbb{\nabla}$ or $ß$ globin mutations is high cost and only available in the capital city. On the other hand, diagnosis of thalassemia becomes more complicated because of high prevalence of iron deficiency anemia in the country [1]. Health survey data in 2001 showed the prevalence of deficiency anemia in infants 0-6 months, infants 6-12 months, and children under five years old were $61.3 \%, 64.8 \%$, and $48.1 \%$, respectively. Iron deficiency should be excluded because it causes falsely low $\mathrm{HbA} 2$ fractions on hemoglobin electrophoresis using micro capillary electrophoresis method. Whenever iron deficiency is detected, before a definitive diagnosis, the hematological parameters must be re-evaluated after iron supplementation. Here is a case of nine months old child with recurrent hemolytic anemia and clinically suspected of having thalassemia.

\section{Case Report}

A seven months old female child was referred to our hospital with fever. She looked very pale since one month. On examination, there was amid hepatomegaly. Laboratory test results can be seen on (Tables 1 \& 2). On peripheral blood film examination, RBCs were dominantly microcytic hypochromic revealing high degree of anisopoikilocytosis [2]. There were teardrop cells, normoblasts, and polychromatic red cells (Figure 1). A clinical diagnosis of hemoglobinopathy was made. Before blood transfusion, an EDTA blood samples was sent to the laboratory for hemoglobin electrophoresis (Figure 2). All the hemoglobin fractions are within normal limit compared to age-specific manufacturer's reference range. Because iron deficiency was already excluded, patient was suggested to repeat the hemoglobin electrophoresis when she is already one year old. Blood transfusion was given gradually.

Table 1: Complete blood count result of the patient.

\begin{tabular}{|c|c|c|c|}
\hline Parameters & Results & Unit & Reference Range \\
\hline Hemoglobin & 3.7 & $\mathrm{~g} / \mathrm{dL}$ & 10.1-12.9 \\
\hline Erythrocyte count & 0,9 & $10^{\wedge} 6 / \bigotimes \mathrm{L}$ & $3.2-5.2$ \\
\hline Hematocrit & 6.5 & $\%$ & $32-44$ \\
\hline MCV & 70.7 & $\mathrm{fL}$ & 73-109 \\
\hline $\mathrm{MCH}$ & 40.2 & pg & $21-33$ \\
\hline MCHC & 56.9 & $\mathrm{~g} / \mathrm{dL}$ & $26-34$ \\
\hline RDW-CV & 30.6 & $\%$ & $11.5-14.5$ \\
\hline Leukocyte count & 13980 & 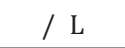 & $6000-17500$ \\
\hline
\end{tabular}




\begin{tabular}{|c|c|c|c|}
\hline Thrombocyte count & 376000 & / & $150000-450000$ \\
\hline Serum iron & 53.15 & \g/dL & $33-193$ \\
\hline TIBC & 194.00 & gg/dL & $228-428$ \\
\hline UIBC & 140.60 & \g/dL & $110-370$ \\
\hline
\end{tabular}

Table 2: Complete blood count results of both parents.

\begin{tabular}{|c|c|c|c|}
\hline Parameters & $\begin{array}{c}\text { Father, } \\
\text { 41 years old }\end{array}$ & $\begin{array}{c}\text { Mother, } \\
\text { 33 years old }\end{array}$ & Unit \\
\hline Hemoglobin & 11.8 & 13.5 & $\mathrm{~g} / \mathrm{dL}$ \\
\hline Erythrocyte count & 6.26 & 6.91 & $10^{\wedge} 6 / \mathbb{\mathrm { L }}$ \\
\hline Hematocrit & 38.6 & 41.2 & $\mathrm{fL}$ \\
\hline MCV & 61.7 & 59.6 & $\mathrm{pg}$ \\
\hline MCH & 18.8 & 19.5 & $\mathrm{~g} / \mathrm{dL}$ \\
\hline MCHC & 30.6 & 32.8 & $\%$ \\
\hline RDW-CV & 17.4 & 17.8 & 10020 \\
\hline Leukocyte count & 7610 & 310000 & $/ \mathbb{L}$ \\
\hline Thrombocyte count & 286000 & $/ \mathbb{L}$ \\
\hline
\end{tabular}

Note: The hemoglobin electrophoresis results of both parents can be seen below.

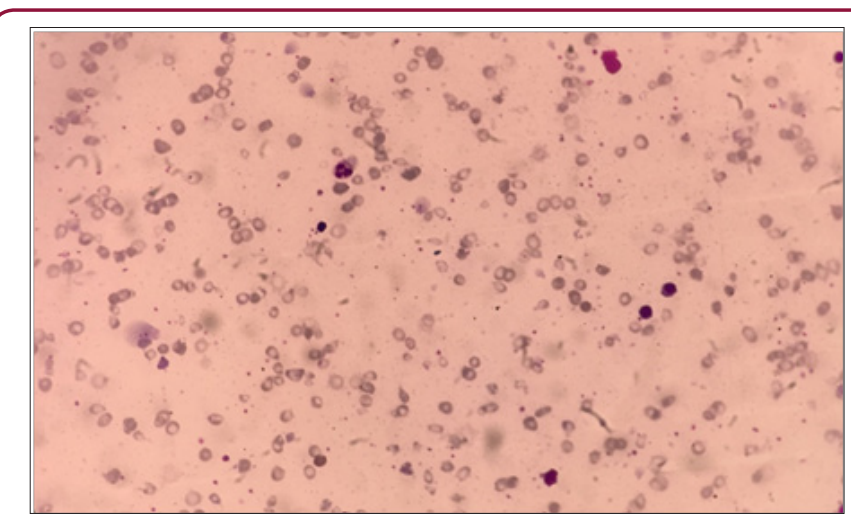

Figure 1: Peripheral blood film.

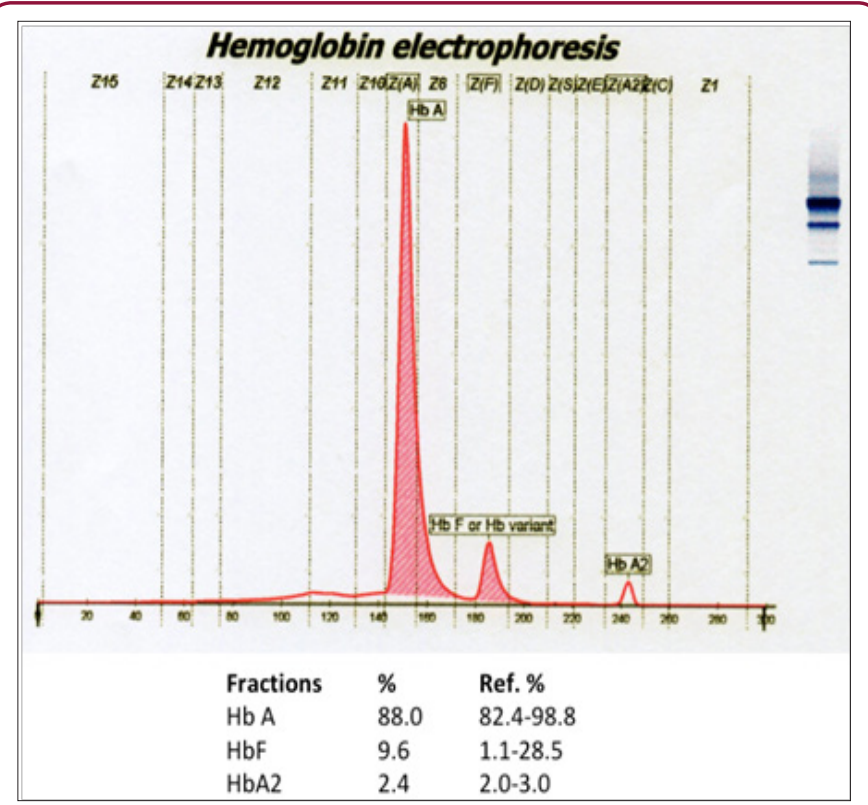

Figure 2: First hemoglobin electrophoresis result seemed normal.
Before discharge, hemoglobin level was $11.3 \mathrm{~g} / \mathrm{dL}$. Unexpectedly, a month later, she came again to the emergency department with fever. She looked very weak and pale. Laboratory examinations showed hemoglobin level $7.5 \mathrm{~g} / \mathrm{dL}$. Before blood transfusion, an EDTA blood sample was sent to the laboratory for hemoglobin electrophoresis (Figure 3). The electrophoresis was, again, within normal limit according to manufacturer's reference range [3]. Because of high suspicion of thalassemia and after excluding other causes of hemolytic anemias, we suggested both parents to have hemoglobinopathy screenings (Figure 4). Hematology results of them can be seen below.

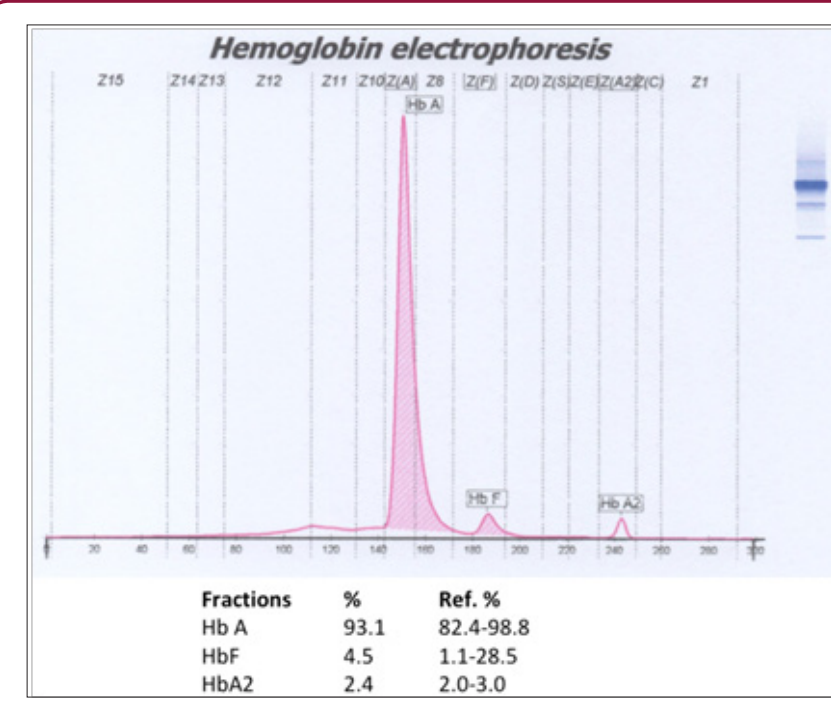

Figure 3: Second hemoglobin electrophoresis. $\mathrm{HbF}$ fraction was decreased compared to the first result.

\section{Discussion}

Thalassemias can be defined as ß-thalassemias depending on the defective globins chain and the underlying molecular defects. In patients with $ß$-thalassemia major, clinical presentations usually 
occurs between 6 and 24 months of life, with severe microcytic, mild jaundice, and hepatosplenomegaly. Hematological diagnosis is based on reduced hemoglobin level $(<7 \mathrm{~g} / \mathrm{dL})$ and very low MCV. The peripheral blood smear shows severe erythrocyte morphologic changes with marked poikilocytosis (speculated tear-drop cells), target cells, and numerous nucleated red blood cells (NRBC). The number of NRBC is related to the degree of ineffective erythropoietin.
Additional tests are required to exclude iron deficiency anemia. After having complete hematological test, quantitative $\mathrm{HbA} 2$ determination is the most valuable test for thalassemia detection. Patients should receive iron supplementation before having hemoglobin electrophoresis test because iron deficiency can falsely lower the HbA2 level.

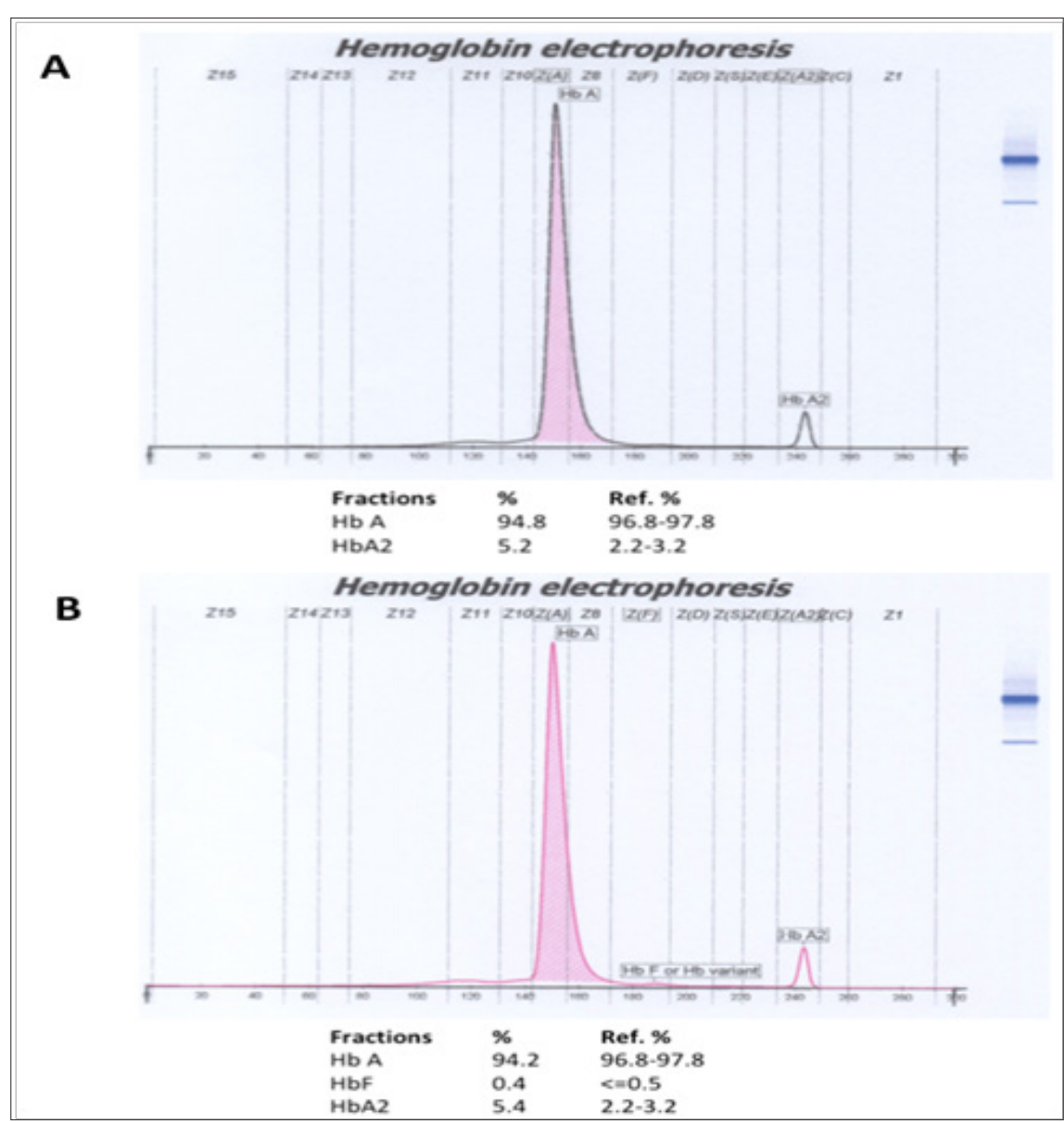

Figure 4: Hemoglobin electrophoresis results of father (A) and mother (B). Both HbA2 fractions were increased, indicated them as B-thalassemia carriers.

The expected normal range for $\mathrm{HbA} 2$ is between 2.4 and $3.2 \%$ in normal subject, while in typical ß-thalassemia carriers, it is between 3.6 and $7 \%$. Values between 3.2 and $3.6 \%$ are considered borderline and they need further investigation, especially in young subjects or couple at risk. The normal range for $\mathrm{HbF}$ in adult life is usually $<1.5 \%$ of total hemoglobin. In the prenatal period, the synthesis of hemoglobin switches from fetal ( $\mathrm{HbF})$ to that of adult $(\mathrm{HbA})$. Factors that control the switching at the molecular or cellular level are as yet unknown. High levels of $\mathrm{HbF}$ in adults are known to be associated with several genetic disorders of goblin chain synthesis, particularly hereditary persistence of fetal hemoglobin (HPFH), thalassemia, and several combinations of thalassemias to other abnormal hemoglobin's. Information on the developmental changes of $\mathrm{HbF}$ levels in tha above conditions during the neonatal period and early infancy is limited. This causes difficulties in establishing the diagnosis of $ß$-thalassemia heterozygotes at this age, as happened in this patient.
Interpreting hemoglobin electrophoresis result of early infants are challenging because there are no established reference range for $\mathrm{HbF}$ for this age group. In this patient, compared to previous result, the decrease of $\mathrm{HbF}$ fraction on second test was most likely caused by blood transfusion one month ago, and was not a natural occurrence. Because the molecular test is not feasible in our region, we suggested the parents to have thalassemia screening. Both of them were classified as ß-thalassemia carriers because they have low hemoglobin levels, low MCVs, low MCHs, and increased $\mathrm{HbF}$ fraction on electrophoresis. Beta-thalassemias are recessive trait. Thus, the clinical relevant phenotypes result from homozygosis or double heterozygosis for different globing gene defects. They can also manifest from co-inheritance of thalassemia trait. Definitive diagnosis of thalassemia for this patient will be done at older age. Blood transfusion should not be done prior to the test to prevent misdiagnosis. 


\section{Conclusion}

Thalassaemia is the leading genetic problem in the Southeast Asia population. A proper laboratory diagnosis is crucial for characterizing the different forms of thalassemia with important implications for diagnosis, prevention, and treatment. The iron status should always be taken into account when evaluating individuals screened for thalassemia. Diagnosis of ß-thalassemia using capillary electrophoresis in neonates and early infants are challenging because there is no exact reference ranges for this age group. In such cases when there is high suspicion of thalassemia but inconclusive hemoglobin electrophoresis result, it is suggested that the parents should have hemoglobinopathy screening.
Submission Link: http://biomedres.us/submit-manuscript.php

This work is licensed under Creative Commons Attribution 4.0 License

\section{References}

1. Brancaleoni V, Di Pierro E, Motta I, Cappellini MD (2016) Laboratory diagnosis of thalassemia. Int J Lab Hematol 38(1): 32-40.

2. Hoffbrand AV, Moss PAH, Pettit JE (2006) Essential Haematology. $5^{\text {th }}$ (Edn.). Blackwell Publishing, Massachusetts, US, pp. 75-80.

3. Metaxotoum Mavromati AD, Antonopoulou HK, Laskari SS, Tsiarta HK, Ladis VA, et al. (1992) Developmental changes in hemoglobin $\mathrm{F}$ levels during the first two years of life in normal and heterozygous ß-thalassemia infants. Pediatrics 69(6): 734-738.

$\begin{array}{ll}\text { BIOMEDICAL } & \text { Assets of Publishing with us } \\ \text { RESEARCHES } & \text { Global archiving of articles } \\ & \text { - Immediate, unrestricted online access } \\ & \text { - Rigorous Peer Review Process } \\ & \text { - Authors Retain Copyrights } \\ \end{array}$

